\title{
IMPLEMENTASI TOTAL QUALITY MANAGEMENT (TQM) DI LEMBAGA PENDIDIKAN TINGGI ISLAM
}

\author{
Oleh: \\ Rika Ariyani \\ Dosen Tetap Manajemen Pendidikan Islam STAI SMQ Bangko
}

\begin{abstract}
Abstrak
Total Quality Management merupakan sebuah konsep yang pada awalnya berasal dari dunia bisnis dan diterapkan dalam dunia perusahaan, tetapi seiring berjalannya waktu TQM juga diterapkan dalam dunia pendidikan. Penerapan TQM dalam pendidikan merupakan sebuah upaya untuk meningkatkan mutu pendidikan. Prinsip umum Total Quality Management (TQM) meliputi beberapa hal, yaitu: mengutamakan kepuasan pelanggan (customer focus organization), keterlibatan seluruh anggota organisasi (people organization), pendekatan yang menekankan pada perbaikan proses (proses approach), pendekatan sistem (system approach), perbaikan secara terus menerus (continual improvement), pengambilan keputusan berdasarkan fakta (factual approach to decision making), dan hubungan dengan supplier yang saling menguntungkan (mutually beneficial relationship).

Prosedur dalam mengimplementasikan TQM dalam lembaga pendidikan pada dasarnya menempuh tiga tahapan sebagai berikut: (1) tahap persiapan, yaitu membentuk tim dan melaksanakan pelatihan bagi tim, (2) Pengembangan sistem, yaitu melakukan pelatihan dan sosialisasi kepada tim yang telah ditentukan, (3) Implementasi sistem, yaitu melaksanakan berdasarkan siklus PDCA (plan, do, check, act). Jika penerapan prinsip-prinsip Total Quality Manajemen dilaksanakan dengan baik dan serius oleh lembaga pendidikan, diyakini peningkatan kualitas output yang diharapkan dapat tercapai dan dapat bersaing dengan lembaga pendidikan lain baik di tingkat Nasional maupun Internasional.
\end{abstract}

Kata Kunci: TQM, Implementasi TQM, Total Quality Management Pendidikan Tinggi 


\section{A. Pendahuluan}

Mutu pada pendidikan tinggi merupakan sebuah keharusan, karena perguruan tinggi adalah salah satu lembaga pendidikan yang memiliki peran penting untuk menyiapkan sumber daya manusia yang berkualitas.Dalam UndangUndang RI No. 12 Tahun 2012 Pasal 51, disebutkan bahwa pendidikan tinggi yang bermutu merupakan pendidikan tinggi yang menghasilkan lulusan yang mampu secara aktif mengembangkan potensinya dan menghasilkan ilmu pengetahuan dan teknologi yang berguna bagi Masyarakat Bangsa dan Negara.

Mutu menjadi kunci sukses suatu perguruan tinggi, terlebih pada era globalisasi saat ini. Perguruan tinggi yang bermutu mendapat kepercayaan berkelanjutan dari pemangku kepentingan internal dan eksternal (Mahasiswa, Dosen, Karyawan, Masyarakat, Dunia Usaha, Asosiasi Profesi dan Pemerintah). Depdiknas menjelaskan bahwa pendidikan tinggi dinyatakan bermutu atau berkualitas, apabila :

1. Perguruan tinggi tersebut mampu menetapkan dan mewujudkan visinya melalui pelaksanaan misinya (aspek deduktif);

2. Perguruan tinggi tersebut mampu memenuhi kebutuhan stakeholders (aspek induktif), berupa; a) Kebutuhan kemasyarakatan (societal needs); b) Kebutuhan dunia kerja (industrial needs); c) Kebutuhan profesional (professional needs).

Perguruan tinggi tidak hanya perlu dilihat sebagai pusat ilmu pengetahuan, pusat penelitian, dan pusat pengabdian kepada masyarakat tetapi juga suatu penghasil ilmu pengetahuan yang perlu bersaing untuk menjamin kelangsungan hidup. Masyarakat juga semakin kritis memilih perguruan tinggi yang diinginkan, dengan pertimbangan utama yang biasa digunakannya adalah apakah setelah lulus akan mudah mendapatkan pekerjaan yang layak atau tidak. Hal ini tentu saja menjadi acuan bagi suatu perguruan tinggi untuk lebih meningkatkan mutu pengelolaannya agar tujuan perguruan tinggi yang telah dicanangkan dapat tercapai.

Salah satu usaha perguruan tinggi yang diharapkan dapat meningkatkan mutu pengelolaannya untuk mencapai tujuannya adalah dengan menerapkan Total Quality Management (TQM). TQM didefenisikan sebagai pendekatan sistem yang 
bertujuan untuk meningkatkan nilai terus menerus kepada pelanggan dengan cara mendesain dan selalu meningkatkan sistem dan proses organisasi sehingga dua prinsip dasar Total Quality Management (TQM) adalah kepuasan pelanggan dan perbaikan terus menerus.

Berdasarkan data yang dikumpulkan, pada tahun 1992 di Amerika Serikat sudah ada 220 Institusi Pendidikan Tinggi yang menerapkan Total Quality Manajemen (TQM). Total Quality Manajemen (TQM) dapat dianggap sebagai metode alternatif untuk meningkatkan mutu pendidikan tinggi karena TQM memiliki berbagai keunggulan dan berdampak sangat positif bagi organisasi, khususnya organisasi pendidikan Tinggi.

Menurut Fandy Tjiptono dan Anastasia Diana, ada enam tantangan pokok yang perlu dikaji dan dikelola secara strategis dalam rangka menerapkan konsep Total Quality Manajemen (TQM) dalam dunia pendidikan tinggi, yakni berkenaan dengan dimensi kualitas, fokus pada pelanggan, kepemimpinan, perbaikan berkesinambungan, manajemen SDM dan manajemen berdasarkan fakta. ${ }^{1}$

Keberhasilan organisasi yang mengimplementasikan TQM ditunjukkandengan adanya komitmen yang tinggi dari semua anggota organisasi, organisasi yang mantap, dan motivasi serta disiplin yang tinggi. Keberhasilan TQM juga sangat ditentukan oleh lima pilarpenyangganya, yaitu produk, proses, organisasi, kepemimpinan, dan komitmen.Keterkaitan di antara lima pilar tersebut dinyatakan oleh Creech ${ }^{2}$ bahwa produk adalah titik fokus untuk tujuan dan pencapaiantujuan organisasi, mutu dalam produk tidak mungkin dicapai tanpa mutudalam proses. Mutu dalam proses tidak mungkin dicapai tanpa organisasiyang tepat. Organisasi yang tepat tidak berarti tanpa kepemimpinan yangsesuai. Komiten yang kuat dari bawah ke atas adalah pilar pendukunguntuk semua yang lain. Setiap pilar tergantung pada keempat yang lain,dan bila salah satu lemah, yang lain juga menjadi lemah.

\footnotetext{
${ }^{1}$ Fandy Tjiptono dan Anastasia Diana, Total Quality Management, (Yogyakarta: ANDI, 2000), Hal. 42

${ }^{2}$ Creech, Lima Pilar (Manajemen Mutu Terpadu) TQM: Cara MembuatTotal Quality Management Bekerja bagi Anda. Terjemahan A.Sindoro, (Jakarta: Binarupa Aksara, 1996), hal. 447
} 


\section{B. Pembahasan}

\section{Pengertian Total Quality Management (TQM)}

Total Quality Management yang disingkat TQM adalah suatu sistem manajemen kualitas yang berfokus pada pelanggan dengan melibatkan semua level karyawan dalam melakukan peningkatan atau perbaikan yang berkesinambungan.

Menurut NasutionTotal Quality Management dapat di defenisikan dari tiga kata yang di milikinya, yaitu total (keseluruhan), quality (kualitas, derajat/ tingkat keunggulan barang atau jasa), management (tindakan, pengendalian pengarahan). Total Quality Manajemen (TQM) merupakan suatu pendekatan dalam menjalankan usaha yang mencoba untuk memaksimumkan daya saing organisasi melalui perbaikan terus menerus atas produk, jasa, tenaga kerja, proses, dan lingkungannya. ${ }^{3}$

Menurut Edward Sallis, Total Quality Management is a philosophy of continuous improvement, which can provide any educational institution with a set of practical tools for meeting andexceeding present and future customers needs,wants, and expectations. ${ }^{4}$

Pendapat di atas dapat dimaknai bahwa Total Quality Management (TQM) adalah sebuah filosofi tentang perbaikan secara terus menerus, yang dapat memberikan seperangkat alat praktis kepada setiap institusi pendidikan dalam memenuhi kebutuhan, keinginan, harapan para pelanggannya, saat ini dan untuk masa yang akan datang.

Sedangkan Goestsch dan Davis mendefinisikan Total Quality Management (TQM) sebagai suatu pendekatan dalam menjalankan suatu usaha yang berusaha memaksimumkan daya saing melalui penyempurnaan terus menerus atas produk, jasa, manusia, proses, dan lingkungan organisasi. ${ }^{5}$ Menurut Fandy $^{6}$, Total Quality Management (TQM) merupakan sistem manajemen yang

\footnotetext{
${ }^{3}$ MN Nasution, Manajemen Mutu Terpadu, (Jakarta: Ghalia Indonesia, 2000), hal. 28

${ }^{4}$ Edward Sallis, Total Quality Management in Education, terj. Ahmad Ali Riyadi dan Fahrurrozi (Jogjakarta: IRCiSoD, 2006), hal. 34

${ }^{5}$ Fandy Ciptono, Aplikasi TQM Dalam Manajemen Perguruan Tinggi, 1999, hal.8

${ }^{6}$ Fandy Tjiptono dan Anastasia Diana, TQM Total Quality Management Edisi Revisi, (Yogyakarta: ANDI, 2002), hal. 4
} 
menyangkut kualitas sebagai strategi usaha dan berorientasi kepada kepuasaan pelanggan dengan melibatkan seluruh anggota organisasi.

Selanjutnya Kanji (1990), sebagaimana diungkapkan kembali oleh Sha'ri M. Yusof dan Elaine Aspinwall, menerangkan bahwa TQM is the way of life of an organisation committed to customer satisfaction through continuous improvement. This way of life varies from organisation to organisation and from one country to another but has certain principles which can be implemented to secure market share, increase profits and reduce costs. TQM didefinisikan sebagai cara hidup organisasi yang diupayakan untuk kepuasan pelanggan melalui perbaikan terus menerus. Cara tersebut berbeda antara organisasi satu dengan yang lain, antara negara satu dengan negara lain, tetapi memiliki prinsip-prinsip tertentu yang dapat diterapkan unstuck menjamin penguasaan pasar, meningkatkan laba, dan mengurangi biaya (Jasuri, volume 2 tahun 2014).

Selain pengertian di atas ada juga yang mendefinisikan Total Quality Management (TQM) sebagai suatu pendekatan yang bertujuan untuk meningkatkan produktivitas usaha, baik secara kulitas maupun kuantitas. ${ }^{7}$ Total Quality Management (TQM) atau manajemen kualitas mutu juga diartikan sebagai suatu filsafat manajemen atau komitmen budaya organisasi untuk memuaskan pelanggan secara konstan lewat perbaikan terus-menerus atas semua proses organisasional, sehingga bisa menghasilkan produk dan jasa yang bermutu tinggi. ${ }^{8}$ Rowley (1995) mengartikan TQM sebagai “ a management philosophy embracing all activities through which the needs and expectations of the customers and the community, and the objective of the organization are satisfied in the most efficient and cost-effective way by maximizing the potential of all employees in a continuing drive for improvement." (Ekroman, editorial jurnal Balitbang pendidikan dan kebudayaan, edisi 34).

Dasar pemikiran perlunya Total Quality Management (TQM) sangatlah sederhana, yakni bahwa cara terbaik agar dapat bersaing dan unggul dalam persaingan global adalah dengan menghasilkan kulitas yang terbaik. Untuk

\footnotetext{
${ }^{7}$ Nanang Fattah, Konsep Manajemen Berbasis Sekolah (MBS) Dan Dewan Sekolah, (Bandung: Pustaka Bani Quraisy: 2004), Hal.117

${ }^{8}$ Benyamin Molan, Glosarium Prentice Untuk Manajemen Dan Pemasaran, (Jakarta: PT. Prenhallindo, 2002), hal.154
} 
menghasilkan kualitas terbaik diperlukan upaya perbaikan berkesinambungan terhadap kemampuan manusia, proses dan lingkungan. Cara terbaik agar dapat memperbaiki kemampuan komponen-komponen tersebut secara berkesinambungan adalah menerapkan Total Quality Management (TQM). ${ }^{9}$

Pengertian mutu atau kualitas akan berlainan bagi setiap orang dan tergantung pada konteksnya. Mutu atau kualitas suatu barang pada umumnya diukur dengan tingkat kepuasan konsumen atau pelanggan. Seberapa besar kepuasan yang diperoleh pelanggan tergantung dari tingkat kecocokan penggunaan masing-masing pelanggan.

Manajemen Mutu Terpadu di lingkungan suatu organisasi non profit termasuk pendidikan tidak mungkin diwujudkan jika tidak didukung dengan tersedianya sumber-sumber untuk mewujudkan kualitas proses dan hasil yang akan dicapai. Di lingkungan organisasi yang kondisinya sehat, terdapat berbagai sumber kualitas yang dapat mendukung pengimplementasian Total Quality Management (TQM) secara maksimal. Menurut Hadari Nawawi ${ }^{10}$, beberapa di antara sumber-sumber kualitas tersebut adalah sebagai berikut:

1. Komitmen Pimpinan Puncak Terhadap Kualitas,

Komitmen ini sangat penting karena berpengaruh langsung pada setiap pembuatan keputusan dan kebijakan, pemilihan dan pelaksanaan program dan proyek, pemberdayaan SDM, dan pelaksanaan kontrol. Tanpa komitmen ini tidak mungkin diciptakan dan dikembangkan pelaksanaan fungsi-fungsi manajemen yang berorentasi pada kualitas produk dan pelayanan umum.

2. Sistem Informasi Manajemen

Sumber ini sangat penting karena usaha mengimplementasikan semua fungsi manajemen yang berkualitas, sangat tergantung pada ketersediaan informasi dan data yang akurat, cukup/lengkap dan terjamin kekiniannya sesuai dengan kebutuhan dalam melaksanakan tugas pokok organiasi.

3. Sumber daya manusia yang potensial

SDM sebagai aset bersifat kuantitatif dalam arti dapat dihitung jumlahnya. Disamping itu SDM juga merupakan potensi yang berkewajiban melaksanakan tugas pokok organisasi untuk mewujudkan eksistensinya.

${ }^{9}$ Fandy Tjiptono dan Anastasia Diana, TQM Total Quality Management Edisi Revisi, h.10

${ }^{10}$ Hadari Nawawi, Manajemen Strategik, (Yogyakarta: Gadjah Mada Pers, 2005), hal. 138-141 
Kualitas pelaksanaan tugas pokok sangat ditentukan oleh potensi yang dimiliki oleh SDM, baik yang telah diwujudkan dalam prestasi kerja maupun yang masih bersifat potensial dan dapat dikembangkan.

4. Keterlibatan semua Fungsi

Semua fungsi dalam organisasi sebagai sumber kualitas, sama pentingnya satu dengan yang lainnnya, yang sebagai satu kesatuan yang tidak dapat dipisahkan. Untuk itu semua fungsi harus dilibatkan secara maksimal, sehingga saling menunjang satu dengan yang lainnya.

5. Filsafat Perbaikan Kualitas secara Berkesinambungan

Sumber-sumber kualitas yang ada bersifat sangat mendasar, karena tergantung pada kondisi pucuk pimpinan, yang selalu menghadapi kemungkinan dipindahkan, atau dapat memohon untuk dipindahkan. Sehubungan dengan itu, realiasi TQM tidak boleh digantungkan pada individu pimpinan sebagai sumber kualitas, karena sikap dan perilaku individu terhadap kualitas dapat berbeda. Dengan kata lain sumber kualitas ini harus ditransformasikan pada filsafat kualitas yang berkesinambungan dalam merealisasikan TQM.

Untuk keberhasilan penerapan TQM tersebut memang tidaklah mudah, diperlukan komitmen dan kerjasama yang baik antara pimpinan, dosen, karyawan, dan semua stakeholder yang terlibat di dalamnya. Implementasi TQM di lembaga pendidikan ada beberapa hal yang harus diperhatikan, pertama, adanya perbaikan secara terus menerus. Kedua, adanya standar mutu, adanya standar ini bertujuan sebagai dasar atau landasan dalam pengembangan mutu. Ketiga, adanya perubahan budaya atau kultur. Budaya yang negatif sebaiknya ditinggalkan, sedangkan budaya yang positif sebaiknya dipertahankan. Keempat, adanya perubahan organisasi. Organisasi yang dianggap kurang efektif hendaknya juga ditinggalkan. Perubahan organisasi ini harus bersifat menyeluruh. ${ }^{11}$

Dari beberapa penjelasan di atas, dapat disimpulkan bahwa TQM merupakan upaya memadukan segenap fungsi dan proses dalam suatu organisasi untuk mencapai perbaikan mutu barang, jasa, ataupun layanan secara terus menerus demi kepuasan pelanggan berdasarkan prinsip-prinsip tertentu. Perbaikan terus menerus sebagai upaya pengembangan diri dilandasi oleh kesadaran bahwa

${ }^{11}$ Aminatul Zahroh, Total Quality Manajemen, (Yogyakarta: Ar-ruzz Media, 2014), hal. 94 
manusia memiliki kemampuan untuk mengubah keadaannya menjadi lebih baik. Hal ini sesuai dengan firman Allah dalam surat Ar-Ra'du ayat 11:

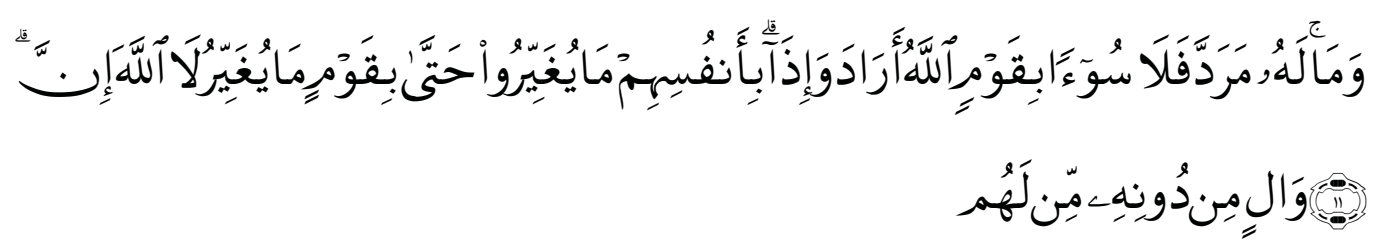

Artinya:

Sesungguhnya Allah tidak merobah keadaan sesuatu kaum sehingga mereka merobah keadaan yang ada pada diri mereka sendiri. dan apabila Allah menghendaki keburukan terhadap sesuatu kaum, Maka tak ada yang dapat menolaknya; dan sekali-kali tak ada pelindung bagi mereka selain Dia.

Tujuan utama TQM dalam pendidikan adalahmeningkatkan kualitas pendidikan secara berkelanjutan, terus menerus,dan terpadu. Upaya peningkatan kualitas pendidikan yang dimaksudkantidak sekaligus, melainkan secara bertahap dituju berdasarkan peningkatankualitas pada setiap komponen pendidikan berdasarkan skala prioritas,yakni sistem layanan akademik. Terdapat beberapa elemen pendukunguntuk mencapai tujuan peningkatan kualitas secara berkelanjutan. Elemenyang ' dimaksudkan meliputi kepemimpinan, pendidikan dan pelatihan,struktur pendukung, komunikasi, penghargaan, dan pengukuran. Semua elemen tersebut perlu diupayakan dan dikondisikanuntuk kepentingan pencapaian tujuan yang diterapkan secara optimal. ${ }^{12}$

\section{Unsur Utama TQM Pendidikan}

Unsur Total Quality Management (TQM) meliputi: (1) Fokus pada pelanggan, baik pelanggan internal maupun eksternal, (2) Memiliki obsesi yang tinggi terhadap kualitas, (3) Menggunakan pendekatan ilmiah dalam mengambil keputusan, (4) Memperbaiki proses secara berkesinambungan, (5) Membutuhkan kerjasama, (6) Memiliki komitmen jangka panjang, (7) Menyelenggarakan pendidikan dan pelatihan, (8) Memberikan kebebasan yang

\footnotetext{
${ }^{12}$ Achmad Supriyanto, Pengembangan dan Implementasi Total Quality Management pada Sistem Layanan Akademik, Jurnal Ilmu Pendidikan, jilid 9 nomor 1 Februari 2002.
} 
terkendali, (9) Memiliki kesatuan tujuan, dan (10) Adanya keterlibatan dan pemberdayaan karyawan. ${ }^{13}$

Sedangkan menurut Slamet (1999) ada lima unsur utama dalam penerapan TQM, yaitu : (1)Berfokus pada pelanggan, (2) Perbaikan pada proses secara sistematik, (3) Pemikiran jangka panjang, 4 Pengembangan sumber daya manusia, dan (5) komitmen pada mutu (Maryamah, edisi Juni 2013).

\section{Prinsip TQM Pendidikan}

Menurut Hensler dan Brunell dalam Nasution ${ }^{14}$, ada empat prinsip utama dalam TQM. Keempat prinsip tersebut adalah sebagai berikut:

1. Kepuasan pelanggan

Semua usaha manajemen dalam TQM diarahkan pada satu tujuan utama yaitu terciptanya kepuasan pelanggan. Pelanggan haruslah merupakan prioritas utama organisasi, karena kelangsungan organisasi tergantung pada pelanggan.

2. Respek terhadap setiap orang.

Karyawan merupakan sumber daya organisasi yang paling bernilai. Oleh karena itu, setiap orang dalam organisasi harus diperlakukan dengan baik dan diberi kesempatan untuk terlibat dan berpartisipasi dalam pengambilan keputusan.

3. Manajemen berdasarkan fakta.

Maksudnya adalah setiap keputusan yang diambil harus berdasarkan pada data, bukan pada perasaan (feeling). Dengan menggunakan data, maka manajemen dan tim dalam organisasi dapat fokus pada situasi yang vital. Dengan demikian, manajemen dapat memprediksikan hasil dari setiap keputusan dan tindakan yang dilakukan.

4. Perbaikan berkesinambungan.

Agar dapat sukses, setiap organisasi perlu melakukan proses sistematis dalam melaksanakan perbaikan secara berkesinambungan. Konsep yang berlaku di sini adalah siklus PDCAA (plan-do-check-act-analyze), yang

\footnotetext{
${ }^{13}$ Fandy Tjiptono dan Anastasia Diana, Total Quality Management, (Yogyakarta: 2003) hal. 4

${ }^{14}$ Nasution M.N, Manajemen Mutu Terpadu, (Jakarta: Ghalia Indonesia, 2010, hal. 30-31
} 
terdiri dari langkah-langkah perencanaan, dan melakukan tindakan korektif terhadap hasil yang diperoleh.

\section{Faktor Kegagalan TQM}

TQM merupakan suatu pendekatan baru dan menyeluruh yang membutuhkan perubahan total atas paradigma manajemen tradisional, komitmen jangka panjang, kesatuan tujuan, dan pelatihan-pelatihan khusus. Selain dikarenakan usaha pelaksanaan yang setengah hati dan harapan-harapan yang tidak realistis, ada pula beberapa kesalahan yang secara umum dilakukan pada saat organisasi memulai inisiatif perbaikan kualitas. Beberapa kesalahan yang sering dilakukan antara lain: ${ }^{15}$

1. Delegasi dan kepemimpinan yang tidak baik dari manajemen senior Inisiatif upaya perbaikan kualitas secara berkesinambungan sepatutnya dimulai dari pihak manajemen di mana mereka harus terlibat secara langsung dalam pelaksanaannya. Jika tanggung jawab tersebut didelegasikan kepada pihak lain maka peluang terjadinya kegagalan sangat besar.

2. Menggunakan pendekatan yang terbatas

Pendekatan yang terbatas tidak dapat secara fleksibel memenuhi tuntutan perkembangan. Ini berarti ada kemandegan atau bahkan akan memberikan kesempatan bagi peningkatan manajemen mutu terpadu. Manajemen mutu terpadu berorientasi pada pelanggan, pelanggan memiliki kepuasan yang selalu berkembang. Oleh karena itu, pendekatan yang sempit dan terbatas tidak sesuai dengan kepuasan pelanggan.

3. Harapan yang terlalu berlebihan dan tidak realistis

Membutuhkan waktu yang lama untuk melatih, mendidik, dan membuat karyawan sadar akan pentingnya kualitas.

\section{TQM dalam Pandangan Islam}

Sebenarnya konsep-konsep TQM bukanlah hal yang baru dalam Islam. Mutu merupakan realisasi dari ajaran Ihsan, yakni berbuat baik kepada semua

15 Tjiptono, Op.Cit, hal. 18-21 
pihak. Ihsan berasal dari kata husn, yang artinya menunjuk pada kualitas sesuatu yang baik dan indah. Selain itu, bisa dikatakan bahwa ihsan berarti kesempurnaan atau terbaik.

Di dalam al-Qur'an Surat al-Qhahash ayat 77 Allah berfirman;

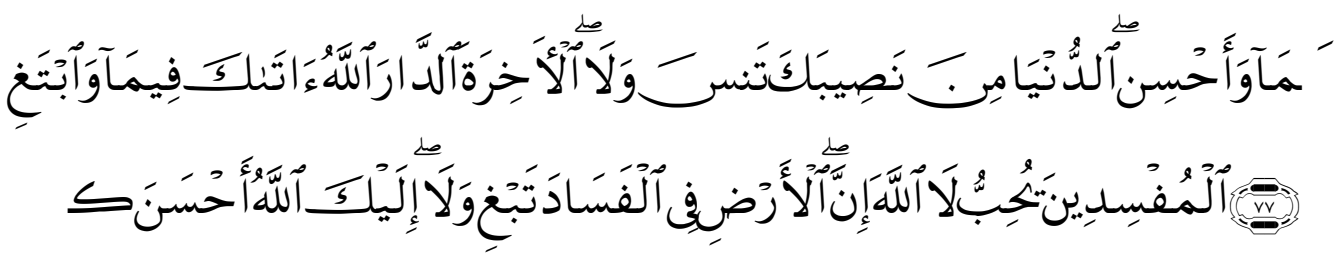

Artinya:

Dan carilah pada apa yang telahdianugerahkan Allah kepadamu (kebahagiaan) negeri akhirat, dan janganlah kamu melupakan bahagianmu dari (kenikmatan) duniawi dan berbuat baiklah (kepada orang lain) sebagaimana Allah Telah berbuat baik, kepadamu, dan janganlah kamu berbuat kerusakan di (muka) bumi. Sesungguhnya Allah tidak menyukai orang-orang yang berbuat kerusakan. ${ }^{16}$

Dari ayat di atas dapat diketahui bahwa sesuatu dikatakan bermutu apabila memberikan memberikan kebaikan, baik kepada dirinya sendiri (lembaga pendidikan itu sendiri), maupun kepada orang lain (stakeholder dan pelanggan), yakni mampu memuaskan pelanggan.Selain itu, proses yang bermutu harus dimulai dengan pemahaman bahwa untuk melakukan sesuatu yang berkualitas harus dilakukan dengan sungguh-sungguh. Dalam surat alKahfi disebutkan:

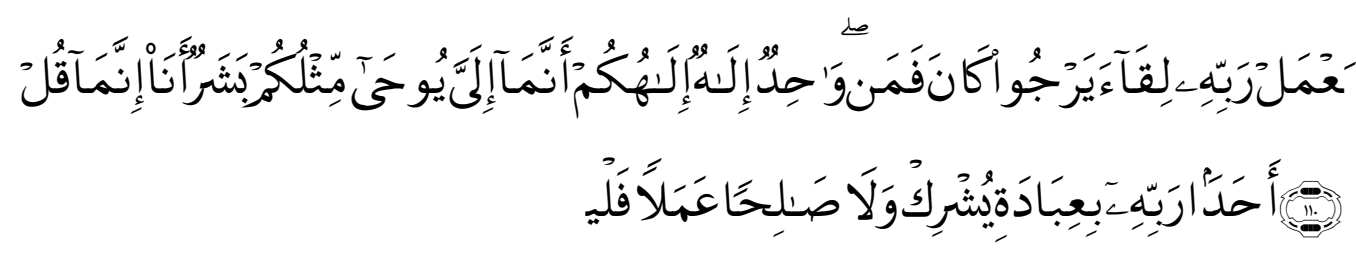

Artinya:

Katakanlah: Sesungguhnya Aku Ini manusia biasa seperti kamu, yang diwahyukan kepadaku: "Bahwa Sesungguhnya Tuhan kamu itu adalah Tuhan yang Esa". barangsiapa mengharap perjumpaan dengan Tuhannya, Maka hendaklah ia mengerjakan amal yang saleh dan

\footnotetext{
${ }^{16}$ Depag RI, Al-Qur'an dan Terjemahan, (Madinah: Mujamma al-Malik Fahd Li Thiba'at al-
} Mushaf, 1998), hal. 623 
janganlah ia mempersekutukan seorangpun dalam beribadat kepada Tuhannya". ${ }^{17}$

Maksud dari kata "mengerjakan amal saleh" dalam ayat di atas adalah bekerja dengan baik (bermutu dan berkualitas), sedangkan kata "janganlah ia mempersekutukan seorang pun dalam beribadah kepada Tuhannya” berarti tidak mengalihkan tujuan pekerjaan selain kepada Tuhan yang menjadi sumber nilai intrinsik pekerjaan manusia. Dalam konteks, manajemen pendidikan Islam, hal tersebut berarti untuk mencapai mutu suatu lembaga pendidikan, maka harus fokus pada proses dan pelanggan.

Keoptimalan dalam melaksanakan proses harus disertai dengan komitmen dalam melaksanakan proses tersebut. Tanpa komitmen yang baik dari anggota suatu lembaga pendidikan Islam, maka tidak mungkin proses yang bermutu akan terbentuk. Selain itu, untuk melakukan proses yang bermutu dibutuhkan personalia yang bermutu dan berdedikasi tinggi.

\section{Implementasi Total Quality Management (TQM) Dalam Lembaga Pendidikan Tinggi Islam}

Dalam rangka melaksanakan perbaikan mutu di perguruan tinggi, termasuk perguruan tinggi Islam, TQM merupakan pendekatan yang tepat. Total Quality Manajemen (TQM) memiliki berbagai keunggulan dan berdampak sangat positif bagi organisasi, khususnya dalam rangka menghadapi persaingan yang semakin kompetitif dan menjaga eksistensi organisasi di era kualitas. Melalui Total Quality Manajemen (TQM), diharapkan mampu memperkecil jurang kesenjangan mutu di segala lini, dapat bersaing dengan mengedepankan mutunya, dan dapat pula meningkatkan mutu pendidikan secara berkelanjutan.

Mutu adalah kepuasan terbaik dan tercapainya kebutuhan/keinginan pelanggan. Mutu menjadi salah satu faktor kunci bagi institusi pendidikan untuk dapat bertahan dan terus berkembang.Penerapan TQM pada perguruan tinggi harus dijalankan atas dasar pengertian dan tanggung jawab bersama,

${ }^{17}$ Ibid, hal. 460 
melalui penerapan TQM perguruan tinggi di Indonesia akan mampu memenangkan persaingan global yang sangat kompetitif.

Di dalam UU RI No. 12 Tahun 2012 pasal 51 disebutkan bahwa pendidikan tinggi yang bermutu merupakan pendidikan tinggi yang menghasilkan lulusan yang mampu secara aktif mengembangkan potensinya dan menghasilkan ilmu pengetahuan dan teknologi yang berguna bagi masyarakat, bangsa, dan negara.

Mutu merupakan agenda terpenting dan memang seharusnya diupayakan serta diwujudkan. Hal ini karena sekolah yang bermutu tentu akan memiliki banyak peminat dibandingkan yang tidak bermutu. Usaha untuk meningkatkan mutu merupakan tugas paling penting bagi lembaga pendidikan yang belum bermutu.

Menurut Veithzal terdapat empat alasan utama mengapa Total Quality Management (TQM) harus di terapkan dalam lembaga pendidikan. Pertama, para pendidik bertanggung jawab terhadap bisnis mereka karena para pendidik merupakan faktor utama bagi peningkatan sekolah. Kedua, pendidikan membutuhkan proses pemecahan masalah yang peka dan fokus pada identifikasi dan penyelesaian penyebab utama yang menimbulkan masalah tersebut. Ketiga, organisasi pendidikan harus menjadi model organisasi belajar semua organisasi. Keempat, sangat mungkin bahwa melalui TQM di lembaga pendidikan orang-orang dapat menemukan mengapa sistem pendidikan yang ada saat ini tidak berjalan dengan baik. Penerapan TQM mungkin dapat memberikan sistem yang lebih baik. ${ }^{18}$

Total Quality Manajemen (TQM) atau manajemen mutu terpadu dalam konteks pendidikan merupakan sebuah filosofi metodologi tentang perbaikan secara terus menerus, yang dapat memberikan seperangkat alat praktis kepada setiap institusi pendidikan dalam memenuhi kebutuhan, keinginan, dan harapan pelanggan, saat ini maupun masa yang akan datang.

Dalam pendidikan tinggi, filosofi $T Q M$ ini juga akan membantu meningkatkan moral, mengurangi biaya, memperbaiki performansi organisasi, dan menanggapi kebutuhan pelanggannya. Untuk itulah maka diperlukan

${ }^{18}$ Veithzal Rivai dan Sylvia Murni, Education Management, (Jakarta: Rajawali Pers, 2010), hal. 483-484 
efektivitas organisasi, partisipasi karyawan dalam penyelesaian masalah dan pembuatan keputusan, komunikasi efektif staf senior dan bawahannya, pendidikan dan pelatihan secara luas, desain yang baik dalam mengenal dan memberi penghargaan untuk memotivasi karyawan, visi yang berorientasi kualitas, benchmarking sebagai alat dalam continuous improvement untuk mewujudkan mahasiswa yang peduli, berpengetahuan, dan dapat melayani masyarakat, serta dukungan dari pimpinan (Emulti et al., 1996).

Menurut Sharples et al. dalam menerapkan filosofi TQM dalam sebuah lembaga pendidikan, ada beberapa hal penting yang perlu diperhatikan, sebagai berikut:

1. Tanggungjawab dan dukungan (commitment)

Komitman yang dimaksud adalah komitmen dari pimpinan lembaga pendidikan yang dikomunikasikan pada semua pihak dalam lembaga pendidikan tersebut. Sehingga timbul komitmen dari semua pihak dalam organisasi atau lembaga pendidikan tersebut.

2. Pendidikan dan Pelatihan (educationand training)

Pendidikan dan pelatihan tersebut bukan hanya untuk karyawan pelaksana atau bagian adminsitrasi, melainkan unuk semua pihak atau semua staf, baik staf edukatif maupun non edukatif. Pendidik-an dan pelatihan ini ditujukan untuk kesiapan dalam menghadapi perubahan dan perbaikan.

3. Penerapan dan praktek (application and practice)

Sebagai suatu filosofi, TQM akan memberikan manfaat bila di-praktekkan atau dilaksanakan. tanpa ada pelaksanaan atau praktek tersebut maka filosofi TQM hanya merupakan slogan yang berisi omong kosong belaka.

4. Standarisasi dan pengenalan (standardization and recognition)

Perlu adanya keseragaman dalam penerapan TQM sehingga kualitas jasa yang disampaikan merupakan jasa yang bersifat standar (robust). Selain itu, TQM harus diperkenalkan pada seluruh pihak dalam organisasi atau lembaga pendidikan tersebut, sehingga penerapannya dapat seragam. ${ }^{19}$

\footnotetext{
${ }^{19}$ Novi Primiani, Total Quality Management Dan Service Quality Dalam Organisasi Pendidikan Tinggi,Cakrawala Pendidikan, Juni 2005, Th. XXIV, No. 2, hal. 186
} 
Sementara itu, menurut Hadari Nawawi, ${ }^{20}$ prosedur dalam mengimplementasikan TQM di lembaga pendidikan adalah sebagai berikut:

1. Persiapan

Tahapan persiapan adalah aktivitas pertama dan utama yang harus dilakukan sebelum TQM dikembangkan dan dilaksanakan. Beberapa langkah yang harus dilakukan adalah membentuk tim dan melaksanakan pelatihan TQM bagi tim. Merumuskan model atau system yang akan dikembangkan sebagai nama implementasi TQM, membuat kebijakan berkaitan dengan komitmen anggota organisasi untuk mendukung TQM, mengkomunikasikan kepada semua anggota organisasi berkaitan dengan adanya perubahan, melakukan analisis faktor pendukung dan penghambat organisasi, dan melakukan pengukuran terhadap kepuasan pelanggan.

2. Pengembangan sistem

Berdasarkan tahapan persiapan, pengembangan system dapat dilakukan dengan langkah-langkah sebagai berikut: peninjauan dan pengembangan model atau sistem yang ada melalui penyusunan dokumen system kualitas, melakukan pelatihan, dan sosialisasi prosedur dan petunjuk kerja kepada tim-tim yang ditentukan secara tuntas, serta melakukan penyiapan akhir, baik sumber daya manusia maupun non manusia secara cermat dan akurat dalam memasuki tahapan implementasi sistem kualitas.

3. Implementasi sistem

Tahapan implementasi sistem menunjuk pada langkah-langkah sebagai berikut: melaksanakan uji coba system jaminan kualitas dalam lingkup tertentu berdasarkan siklus PDCA (plan, do, check, act), anggota tim menginformasikan kepada pimpinan maupun steering commite berkaitan dengan uji coba sistem jaminan kualitas yang telah dilaksanakan secara rinci, tim mengumpulkan data dan informasi dari pelanggan, melakukan tindakan koreksi dan pencegahan sesuai dengan harapan pelanggan, dan mendiskusikan/melaksanakan rapat pemimpin dan pelaksana system jaminan kualitas berkaitan dengan seluruh balikan yang ada untuk menghasilkan atau

${ }^{20}$ Hadari Nawawi, Manajemen Strategik, (Yogyakarta: Gadjah Mada Pers, 2005), hal. 47 
membuat modifikasi proses yang diharapkan secara terus menerus dan berkesinambungan.

Keberhasilan aplikasi TQM atau manajemen mutu terpadu di sebuah lembaga pendidikan dapat diukur dari tingkat kepuasan pelanggan, baik internal maupun eksternal. Sebuah lembaga pendidikan dikatakan berhasil jika mampu memberikan layanan sesuai harapan pelanggan. Dengan kata lain, mahasiswa dan masyarakat merasa puas dengan layanan kampus, pihak pemakai atau penerima lulusan merasa puas karena menerima lulusan dengan kualitas tinggi dan sesuai harapan, dosen dan karyawan pun merasa merasa puas dengan layanan kampus.

Mutu pendidikan akan terjamin ketika manajer di lembaga pendidikan tersebut melaksanakan fungsi manajemen dengan baik dan dibarengi komponen pendidikan yang berkualitas atau adanya sinergitas yang berorientasi pada mutu pendidikan antara pemimpin dengan seluruh civitas akademika di lembaga pendidikan tersebut.

Pendidikan yang bermutu ditentukan oleh beberapa komponen yang terkait, mulai dari input (masukan), proses, dan output (keluaran) serta dengan pengelolaan manajemen yang bagus. Keberhasilan lembaga pendidikan sebagai organisasi dalam mencapai prestasi yang membanggakan tidaklah diperoleh dengan begitu saja, tetapi sangat dipengaruhi oleh berbagai faktor pendukungnya.

Menurut Aminatul Zahroh ${ }^{21}$, untuk dapat mencapai total quality manajemen (TQM) atau peningkatan mutu pendidikan sebagaimana yang diharapkan oleh lembaga pendidikan, ada beberapa hal yang perlu diperhatikan: 1) Kerjasama tim (team work), 2) Keterlibatan stakeholders, 3) Keterlibatan siswa, dan 4) Keterlibatan orang tua.

Kerjasama tim di sebuah lembaga pendidikan sangat berperan demi kemajuan dan perkembangan. Para dosen, pimpinan, karyawan, staf, dan juga masyarakat di sekitar lembaga pendidikan juga ikut berpartisipasi dalam hal ini. Dengan adanya kerjasama dan keterlibatan semua komponen akan terbentuk efektivitas dari sebuah tim kerja.

Selain kerjasama tim, keterlibatan semua stakeholder juga tidak kalah penting. Stakeholder adalah para pengguna jasa pendidikan. Mereka terdiri dari

${ }^{21}$ Aminatul Zahroh, Total Quality Manajemen, (Yogyakarta: Ar-ruzz Media, 2014), hal. 56 
para pimpinan dan pengusaha. Keterlibatan mereka sangat membantu para mahasiswa untuk memperoleh dan mengembangkan karier. Dengan adanya hubungan antara pihak lembaga dengan para pengguna jasa pendidikan akan menjadikan ketertarikan tersendiri untuk memasuki lembaga pendidikan tersebut.

Keterlibatan mahasiswa dan keterlibatan orangtua dalam TQM juga harus diperhatikan. Mahasiswa adalah individu yang memerlukan layanan pendidikan maksimal. Dalam proses peningkatan mutu pendidikan perlu adanya peran serta mahasiswa karena mahasiswa merupakan salah satu tolak ukur mutu pendidikan.

Selanjutnya, dalam penerapan TQM pada industri jasa pendidikan, menurut Herbert ada empat pendekatan atau cara yang dapat digunakan, yaitu sebagai berikut:

1. Menggunakan filosofi atau prinsip $T Q M$ dalam memperbaiki fungsi operasi dan adminsitrasi pada sebuah lembaga pendidikan

$T Q M$ adalah filosofi perbaikan secara terus-menerus dan berkesinambungan yang dapat menyediakan bagi lembaga pendidikan seperangkat alat-alat untuk dapat memenuhi atau melebihi kebutuhan, keinginan, dan harapan pelanggan. Keinginan, kebutuhan, dan harap-an pelanggan yang dalam hal ini adalah pelanggan iinternal mau-pun eksternal terhadap seluruh kegiatan operasional dan administrasi suatu lembaga pendidikan. Oleh karena itu prinsip TQM harus diperkenalkan dan diterapkan pada fungsi-fungsi akademis dan non akademis. Pelanggan tentu saja menginginkan pelayanan yang diberikan oleh bagian administrasi tepat waktu, cepat, benar, dan memuaskan. TQM sebagai suatu filosofi dapat digunakan untuk mengadakan perbaikan-perbaikan dalam memberikan pelayanan tersebut. Perbaikan tersebut bukan berupa perubahan total, tetapi perubahan kecil setiap hari dan menyangkut perubahan hingga halhal yang kecil dengan menganut prinsip Kaizen yaitu little better everyday.

2. Memasukkan $T Q M$ sebagai salah satu mata kuliah

Kombinasi perubahan lingkungan eksternal dan tekanan dunia bisnis membuat $T Q M$ menjadi isu yang sangat penting pada suatu lembaga pendidikan. Bila $T Q M$ telah digunakan sebagai suatu pendekatan dalam mengelola bisnis jasa pendidikan, maka secara logis juga harus dapat dimasukkan dalam kurikulum, dalam artian pada lembaga pendidikan tersebut terdapat mata kuliah yang 
khusus berbicara mengenai Total Quality Management. Hal ini mendorong lembaga-lembaga pendidikan untuk mengidentifikasi pelanggan primer dan memberikan kesempatan untuk mempelajari prinsip TQM.

3. Menggunakan TQM sebagai metode pengajaran di kelas

Hal ini berarti $T Q M$ harus dijadikan sebagai inti dari proses pembelajaran yang dilakukan.

4. Menggunakan $T Q M$ untuk mengelola kegiatan-kegiatan penelitian

Suatu lembaga pendidikan tinggi atau universitas mempunyai misi utama yaitu pendidikan/ pengajaran, penelitian, dan pelayanan atau pengabdian pada masyarakat. Kegiatan penelitian tidak pernah terlepas dari tri dharma perguruan tinggi. Dalam melaksanakan penelitian juga perlu pengalolaan terhadap sumber daya untuk penelitian tersebut. Oleh karena itu perlu pendidikan dan pelatihan dalam kegiatan penelitian tersebut. Selain itu, komitmen dari pimpinan untuk dapat mendukung kegiatan tersebut sangat diperlukan disamping koomitmen dari para peneliti itu sendiri. Hasil penelitian tersebut juga harus selalu diperbaiki dan disempurnakan. Bisa jadi, penelitian tersebut dilakukan atas permintaan dari pihak tertentu yang mempercayai lembaga pendidikan tersebut untuk meneliti permasalahan yang terjadi pada pihak yang meminta penelitian tersebut. Sehingga, pihak yang meminta dilakukannnya penelitian itulah pelanggannya di mana kepuasannya harus diwujudkan dengan berpedoman pada filosofi $T Q M$.

\section{Hambatan Dalam MengimplementasikanTotal Quality Management} (TQM) di Lembaga Pendidikan Tinggi

Dalam rangka mengimplementasikan TQM di lembaga pendidikan Tinggi tentu tidak luput dari hambatan-hambatan yang dialami.Pelaksanaan $T Q M$ merupakan pekerjaan yang cukup berat dan memerlukan waktu yang lama.Tjiptono dan diana 2000 : 4 menyatakan bahwa faktor yang menyebabkan kegagalan dalam mengimplementasikan TQM antara lain: (1) perubahan yang menyeluruh (paradigma manajemen, komitmen, tujuan, dan pelatihan) tidak terpenuhi; (2) usaha setengah hati dan harapan tidak realistis; (3) kesalahan delegasi dan kepemimpinan, tim, proses penyebarluasan, 
pendekatan terbatas, dan pemberdayaan yang prematur. Kendala lain yang dihadapi oleh organisasi antara lain penciptaan lingkungan yang mendukung usaha perbaikan dan berorientasi pada mutu masih kurang, pemahaman terhadap perencanaan strategis dan dialogis masih kurang, pemberdayaan sumber daya manusia masih kurang, komitmen dan partisipasi karyawan program perbaikan mutu masih kurang, dan sistem informasi manajemen pendukung pelaksanaan program peningkatan mutu kurang mendapat perhatian.

Menurut Matthew, hambatan dalam penerapan TQM pada organisasi pendidikan tinggi seringkali berkaitan dengan misi idealis, kurang adanya kesepakatan dalam pengertian dan penerapan kualitas, kebebasan, dan kedewasaan akademik, dan kemampuan administratif.

Sedangkan menurut Hessel 2003 98, beberapa hambatan dalam mengimplementasikan TQM di lembaga pendidikan tinggi Indonesia adalah:

1. Kurangnya komitmen manajemen puncak.

2. Kurangnya dukungan infrastruktur untuk implementasi TQM.

3. Kurangnya pengetahuan tentang konsep TQM yang akan mempersulit karyawan untuk menerima dan menerapkan konsep TQM.

4. Budaya organisasi kurang mendukung implementasi TQM, di mana belum sepenuhnya berfokus pada kepuasan pelanggan.

Bebeberapa kendala tersebut perlu mendapatkan perhatian khusus dari pimpinan lembaga.Kesuksesan dalam penerapan TQMdi suatu lembaga pendidikan tergantung dari visi yang digunakan oleh para guru atau dosen, guru besar, dan para pemangku kepentingan lainnya, karena yang berperan penting dalam mengimplementasikan TQM adalah faktor SDM yang ada di lembaga tersebut. Dengan demikian kunci keberhasilan penerapan TQM antara lain komitmen yang tinggi dari para stakeholder lembaga.

\section{Penutup}

Implementasi TQMmerupakan salah satu upaya untuk meningkatkan kualitas pendidikan di Indonesia, khususnya pendidikan tinggi Islam. Penerapan TQM tidak memerlukan peralatan atau sistem manajemen baru, melainkan komitmen atau kesadaran untuk mengadakan perubahan budaya 
yang berorientasi pada peningkatan kualitas dan perbaikan seluruh proses secara terus-menerus, menyeluruh, dan berkesinambungan. TQM dapat diterapkan dalam organisasi apa pun tanpa terkecuali. Apabila diikuti dengan benar maka keberhasilan akan berada di tangan, baik individu maupun organisasi.

Prinsip-prinsip TQM yaitu: (1) Kepuasan pelanggan, (2) Respek terhadap setiap orang, (3) Manajemen berdasarkan fakta. Sedangkan prosedur dalam mengimplementasikan TQM di lembaga pendidikan adalah sebagai berikut: 1) Persiapan, 2) Pengembangan sistem, 3) Implementasi sistem. 


\section{DAFTAR PUSTAKA}

Achmad Supriyanto, Pengembangan dan Implementasi Total Quality Management pada Sistem Layanan Akademik, Jurnal Ilmu Pendidikan, Jilid 9, Nomor 1Februari 2002

Aminatul Zahroh, Total Quality Manajemen, Yogyakarta: Ar-ruzz Media, 2014.

Benyamin Molan, Glosarium Prentice Untuk Manajemen Dan Pemasaran, Jakarta: PT. Prenhallindo, 2002.

Creech, Lima Pilar (Manajemen Mutu Terpadu) TQM: Cara Membuat Total Quality Management Bekerja bagi Anda. Terjemahan A. Sindoro, Jakarta: Bina rupa Aksara, 1996.

Depag RI, Al-Qur'an dan Terjemahan, Madinah: Mujamma al-Malik Fahd Li Thiba'at al-Mushaf, 1998.

Edward Sallis, Total Quality Management in Education, terj. Ahmad Ali Riyadi dan Fahrurrozi Jogjakarta: IRCiSoD, 2006.

Ekroman, Sri Soejatminah. Quality Assurance dalam Sistem Pendidikan Tinggi. Balitbang Diknasmen DIKTI, PLSP Kebudayaan SETJEN ITJEN. Editorial Jurnal Pendidikan dan Kebudayaan edisi 34.

Emulti, D., Kathwala, Y., dan Manippallil, M.. Are Total Quality Management Programs In Higher Education Worth The effort ? International Journal of Quality and Reliability Management, 1996.

Fandy Tjiptono dan Anastasia Diana, Total Quality Management, Yogyakarta: ANDI, 2000.

Hadari Nawawi, Manajemen Strategik, Yogyakarta: Gadjah Mada Pers, 2005.

Herbert, F. J., Dellana, S. A., dan Bass, K. E.. Total Quality Management In Business School: The Faculty Viewpoint. Sam Advanced Management Journal, Autumn, 1995.

Jasuri, Implementasi Total Quality Management Pada Kelas Internasional dan Akselerasi MTS PPMI Assalaam Surakarta, Jurnal Manajemen Pendidikan Islam, Volume 2 Nomor 1, thn 2014.

Maryamah, Total Quality Management (TQM) dalam Konteks Pendidikan, TA’DIB, Vol. XVIII, No. 01, Edisi Juni 2013

Nanang Fattah, Konsep Manajemen Berbasis Sekolah (MBS) Dan Dewan Sekolah,Bandung: Pustaka Bani Quraisy: 2004.

Nasution M.N, Manajemen Mutu Terpadu, Jakarta: Ghalia Indonesia, 2010. 
Novi Primiani, Total Quality Management Dan Service Quality Dalam Organisasi Pendidikan Tinggi,Cakrawala Pendidikan, Juni 2005, Th. XXIV, No. 2, hal. 186

Veithzal Rivai dan Sylvia Murni, Education Management, Jakarta: Rajawali Pers, 2010. 